\title{
Factors Affecting the Survival of Ram Spermatozoa during Liquid Storage and Options for Improvement
}

\author{
Natalie Rizkallah *, Caitlin G. Chambers (D), Simon P. de Graaf and Jessica P. Rickard (D) \\ School of Life and Environmental Sciences, Faculty of Science, University of Sydney, \\ Sydney, NSW 2006, Australia; caitlin.chambers@sydney.edu.au (C.G.C.); \\ simon.degraaf@sydney.edu.au (S.P.d.G.); jessica.rickard@sydney.edu.au (J.P.R.) \\ * Correspondence: natalie.rizkallah@sydney.edu.au
}

Citation: Rizkallah, N.; Chambers, C.G.; de Graaf, S.P.; Rickard, J.P. Factors Affecting the Survival of Ram Spermatozoa during Liquid Storage and Options for Improvement. Animals 2022, 12, 244. https:// doi.org/10.3390/ani12030244

Academic Editor: Rosa Maria L.N. Pereira

Received: 25 November 2021

Accepted: 17 January 2022

Published: 20 January 2022

Publisher's Note: MDPI stays neutral with regard to jurisdictional claims in published maps and institutional affiliations.

Copyright: (C) 2022 by the authors. Licensee MDPI, Basel, Switzerland. This article is an open access article distributed under the terms and conditions of the Creative Commons Attribution (CC BY) license (https:// creativecommons.org/licenses/by/ $4.0 /)$.
Simple Summary: The success of semen preservation is vital for the use of artificial reproductive technologies in sheep. However, reduced temperatures can cause significant damage to the sperm cell. Recent investigations in other species have identified room-temperature liquid storage as a viable alternative if spermatozoa are protected from the increased risk of lipid peroxidation, a side effect of unaltered metabolism. The following review aims to summarise the factors which contribute to the survival of ram spermatozoa during liquid storage and the role of pro-survival factors and antioxidants in helping to ameliorate the damaging effects caused by lipid peroxidation on fertility. This would contribute towards establishing a new method of semen preservation for the sheep industry which maximises fertility following storage and artificial insemination.

Abstract: Semen preservation is an essential component of reproductive technologies, as it promotes genetic gain and long-distance semen transport and multiplies the number of ewes able to be inseminated per single ejaculate. However, the reduced temperature during cold storage at 5 or $15{ }^{\circ} \mathrm{C}$ inflicts sub-lethal damage to spermatozoa, compromising sperm quality and the success of artificial breeding. New and emerging research in various species has reported the advantages of storing spermatozoa at higher temperatures, such as $23{ }^{\circ} \mathrm{C}$; however, this topic has not been thoroughly investigated for ram spermatozoa. Despite the success of storing spermatozoa at $23{ }^{\circ} \mathrm{C}$, sperm quality can be compromised by the damaging effects of lipid peroxidation, more commonly when metabolism is left unaltered during $23{ }^{\circ} \mathrm{C}$ storage. Additionally, given the biosafety concern surrounding the international transport of egg-yolk-containing extenders, further investigation is critical to assess the preservation ability of synthetic extenders and whether pro-survival factors could be supplemented to maximise sperm survival during storage at $23^{\circ} \mathrm{C}$.

Keywords: semen preservation; sheep; room temperature; viability; egg yolk

\section{Introduction}

Semen preservation is defined as the lengthening of the fertile lifespan of spermatozoa by maintaining the functional, ultrastructural, and biochemical properties of the spermatozoa [1]. By prolonging the fertile lifespan of spermatozoa, ejaculate efficiency per elite ram improves, allowing semen to be transported across greater distances and to inseminate more ewes [2], ultimately accelerating genetic gain [1,3].

Semen preservation involves storing spermatozoa in either a liquid or cryopreserved state [4]. Liquid preservation of spermatozoa involves slowing biochemical function by cooling spermatozoa to temperatures between $0-15^{\circ} \mathrm{C}$. However, the fertility of chilled or fresh ram spermatozoa post liquid preservation is limited to $24 \mathrm{~h}$, with an average decline of 10-35\% in fertility per day using cervical insemination [1]. This limit restricts the maximum distance between the sire location and place of insemination [1]. Therefore, producers who wish to take advantage of semen collected from international sires must rely on the frozen 
storage of spermatozoa. Indefinite storage of semen involves cryopreservation, which completely halts biochemical functioning [5]. Cryopreservation involves freezing semen in straws or pellets at $-196^{\circ} \mathrm{C}$ using liquid nitrogen $[1,6]$.

Despite extensive development on the type of extenders used [1,7], modification of the cooling and freezing processes [5], and the concentration of spermatozoa which is stored [1], the process can still inflict considerable ultrastructural $[6,8,9]$, biochemical [8,9], and thermal damage $[1,6,9]$, leading to reduced or varied fertility rates post thaw for the industry.

Thermal damage, also known as cold shock, is heightened in rams due to their low intramembrane cholesterol-to-phospholipid ratio present on the sperm membrane [7]. Cold shock damage can reduce ram sperm motility and viability up to $60 \%$ post thaw [7]. Furthermore, frozen-thawed ram spermatozoa also struggle to penetrate the ovine cervix and achieve fertilisation, recording a pregnancy rate of only $20-30 \%$ following cervical artificial insemination [7,9]. As such, producers must rely on laparoscopic artificial insemination to take advantage of the benefits associated with frozen-thawed spermatozoa, which requires the injection of spermatozoa directly into the uterus (60-80\% fertility success) [10-12]. This process is expensive, requires specialised skills, and raises significant animal welfare concerns in some jurisdictions. Therefore, research into developing an alternative storage method that preserves ram sperm fertility greater than $24 \mathrm{~h}$ and reduces sub-lethal thermal damage would be helpful for the sheep artificial reproductive technology toolbox.

There has been growing interest in using ambient-temperature storage $\left(23^{\circ} \mathrm{C}\right)$ to maintain sperm survival during preservation (Table 1). In particular, studies such as Wusiman et al. (2012) demonstrated that ram spermatozoa stored at $23{ }^{\circ} \mathrm{C}$ for $24 \mathrm{~h}$ did not differ in viability, acrosome integrity, or mitochondrial membrane potential when compared to spermatozoa stored at $4{ }^{\circ} \mathrm{C}$ for $48 \mathrm{~h}$, also achieving a similar pregnancy rate to that of fresh spermatozoa. While the concept of storing ram spermatozoa at $23^{\circ} \mathrm{C}$ has been investigated, the study mentioned above by Wusiman et al. (2012) did not report any accompanying sperm motility or kinematic results and only assessed the ability of eggyolk-based extenders to support sperm function [12]. A systemic review or comparison of the traditional ram sperm extenders and their performance at different temperatures would be beneficial in validating this storage technique for the industry (Table 1). Furthermore, despite these studies reporting encouraging results on the impact of $23{ }^{\circ} \mathrm{C}$ storage on spermatozoa, many studies also highlighted an accentuated risk of lipid peroxidation damage when stored at $23^{\circ} \mathrm{C}[13,14]$.

Lipid peroxidation is a metabolic process where reactive oxygen species (ROS) are formed by the oxidative degeneration of polyunsaturated fatty acids [13]. This process is accelerated at higher temperatures (as metabolism occurs unrestricted, leading to ROS overproduction $[4,14]$ ) and negatively impacts sperm function $[14,15]$.

Reduced lipid peroxidation damage has been reported in some species such as stallions [16], rams [17,18], and buffalo [19] when extenders are supplemented with prosurvival factors, e.g., L-carnitine, pyruvate, and/or melatonin. However, research fully defining the antioxidant-like effect of these pro-survival factors in ram spermatozoa during $23{ }^{\circ} \mathrm{C}$ storage is limited. Therefore, research into these factors' ability to minimise lipid peroxidation and reduce ROS while supporting sperm functionality at $23^{\circ} \mathrm{C}$ is required.

As such, this literature aims to review the current knowledge on the factors that impact the quality of ram spermatozoa during liquid preservation at 5,15 , and $23^{\circ} \mathrm{C}$, with a focus on temperature-induced liquid peroxidation at room temperature $\left(23^{\circ} \mathrm{C}\right)$. Additionally, methods to reduce the deleterious effects of lipid peroxidation on ram spermatozoa following storage at $23^{\circ} \mathrm{C}$ will be explored, including the supplementation of the pro-survival factors L-carnitine, pyruvate, and melatonin. The findings examined in this review will help identify the components required to preserve the quality and lifespan of ram spermatozoa following liquid storage at $23^{\circ} \mathrm{C}$, offering the ovine industry an alternative to the cryopreservation of spermatozoa. 
Table 1. Summary of publications investigating semen storage temperatures between $20-37^{\circ} \mathrm{C}$ in various species.

\begin{tabular}{|c|c|c|c|c|}
\hline Species & Temp & Extender & Result & Reference \\
\hline \multirow[t]{5}{*}{ Ram } & $\begin{array}{c}4^{\circ} \mathrm{C} \\
23^{\circ} \mathrm{C} \\
-196^{\circ} \mathrm{C} \\
\end{array}$ & Citrate-glucose-EY ${ }^{1}$ & $\begin{array}{l}\text { Higher fertility at } 23^{\circ} \mathrm{C} \text { and } 4{ }^{\circ} \mathrm{C} \text { when } \\
\text { compared to }-196^{\circ} \mathrm{C} \text { at } 24 \mathrm{~h}\end{array}$ & [12] \\
\hline & $\begin{array}{l}5{ }^{\circ} \mathrm{C} \\
20^{\circ} \mathrm{C}\end{array}$ & $\begin{array}{c}\text { Milk-based } \\
\text { Sodium-citrate-based } \\
\text { Tris-citrate-fructose }+ \text { EY }{ }^{1}\end{array}$ & $\begin{array}{l}\text { Sodium-based and TRIS with and without EY } \\
\text { maintained the highest viability at } 72 \mathrm{~h}\end{array}$ & [20] \\
\hline & $\begin{array}{l}5{ }^{\circ} \mathrm{C} \\
24{ }^{\circ} \mathrm{C}\end{array}$ & Tes-Tris-fructose solution with EY * & $\begin{array}{l}\text { Higher sperm abnormality in sperm stored at } \\
24^{\circ} \mathrm{C} \text { when compared to } 5^{\circ} \mathrm{C} \text { at } 48 \mathrm{~h}\end{array}$ & [21] \\
\hline & & & $\begin{array}{l}\text { Higher embryo cleavage at } 24^{\circ} \mathrm{C} \text { when } \\
\text { compared to } 5^{\circ} \mathrm{C} \text { at } 48 \mathrm{~h}\end{array}$ & \\
\hline & $\begin{array}{l}4{ }^{\circ} \mathrm{C} \\
20^{\circ} \mathrm{C} \\
37^{\circ} \mathrm{C}\end{array}$ & Tyrode's albumin lactate pyruvate $+\mathrm{EY}^{1}$ & $\begin{array}{l}\text { Higher TM at } 20^{\circ} \mathrm{C} \text { and } 37^{\circ} \mathrm{C} \text { when } \\
\text { compared to } 4{ }^{\circ} \mathrm{C} \text { at } 72 \mathrm{~h}\end{array}$ & [22] \\
\hline Bull & $\begin{array}{c}5^{\circ} \mathrm{C} \\
18^{\circ} \mathrm{C}\end{array}$ & $\begin{array}{c}\text { Cap }^{1} \\
\text { BioXcell } \\
\text { INRA96 }\end{array}$ & $\begin{array}{l}\text { Higher TM in Cap extender when compared } \\
\text { to BioXcell and INRA96 at } 72 \mathrm{~h}\end{array}$ & [23] \\
\hline \multirow[t]{2}{*}{ Buck } & $\begin{array}{l}5^{\circ} \mathrm{C} \\
15^{\circ} \mathrm{C} \\
25^{\circ} \mathrm{C}\end{array}$ & $\begin{array}{l}\text { PBS supplemented with } 10 \mathrm{mM} \text { pyruvate } \\
\text { or lactase }\end{array}$ & $\begin{array}{l}\text { Higher } \mathrm{PM} \text { at } 15^{\circ} \mathrm{C} \text { when compared to } 5^{\circ} \mathrm{C} \\
\text { and } 25^{\circ} \mathrm{C} \text { at } 168 \mathrm{~h}\end{array}$ & [24] \\
\hline & & & $\begin{array}{l}\text { Higher viability at } 15^{\circ} \mathrm{C} \text { when compared to } \\
5^{\circ} \mathrm{C} \text { and } 25^{\circ} \mathrm{C} \text { at } 168 \mathrm{~h}\end{array}$ & \\
\hline Stallion & $15-20{ }^{\circ} \mathrm{C}$ & INRA96 & $\begin{array}{l}\text { Lower TM at } 20^{\circ} \mathrm{C} \text { when compared to } 5^{\circ} \mathrm{C} \text { at } \\
\qquad 12 \mathrm{~h}\end{array}$ & [25] \\
\hline & $\begin{array}{l}5{ }^{\circ} \mathrm{C} \\
15^{\circ} \mathrm{C} \\
20{ }^{\circ} \mathrm{C}\end{array}$ & $\begin{array}{c}\text { SM }^{1} \\
\text { Cap }^{1} \\
\text { NFMS }^{1}\end{array}$ & $\begin{array}{l}\text { Higher fertility PM in Cap than SM and NFM } \\
\text { at all temperatures at } 72 \mathrm{~h}\end{array}$ & [26] \\
\hline
\end{tabular}

\section{Factors Affecting the Survival of Spermatozoa during Liquid Storage}

During semen preservation, various factors such as temperature, storage concentration, and extender can influence sperm quality and survivability during storage. When developing a new semen preservation technique or extender, understanding the relationship between storage conditions and sperm quality is crucial to prevent sperm damage. Therefore, an in-depth examination of temperature, the concentration of sperm, and the extender used on the survivability of sperm during storage is presented below.

\subsection{Temperature}

Cold shock or thermal damage of sperm occurs when the ambient temperature surrounding the sperm cell is reduced rapidly, significantly influencing the organisation of both suspended and free intramembrane components [27]. Cold shock damage is a significant consequence of the reorganisation of these intramembrane components, which creates lipid-lipid agglutinations, disrupts cell signalling, and forms particle-free zones [27,28]. These particle-free zones reduce membrane integrity and selective permeability, allowing unrestricted ionic transport across the membrane (Figure 1); [28]. this impairment has been reported in boar spermatozoa, recording a viability of $36.7 \%$ and an acrosome integrity of $20.2 \%$ following storage at $5{ }^{\circ} \mathrm{C}$ for $4 \mathrm{~h}$. These results are significantly lower than that of freshly stored boar spermatozoa, which demonstrated $74.4 \%$ viability and a $44.2 \%$ acrosome-intact population [29]. Studies such as these demonstrate the significant 
impact reduced temperatures have on the quality of preserved spermatozoa and the need for optimising these methods.

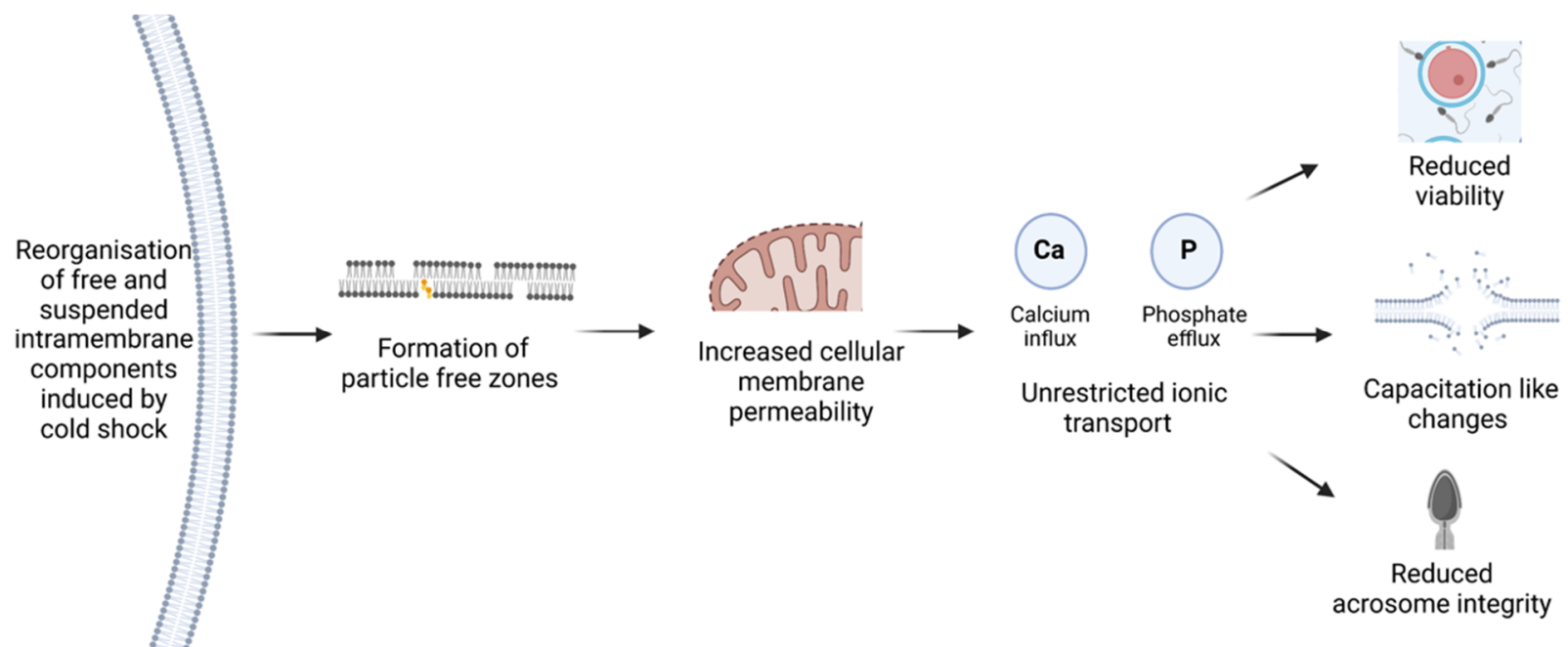

Figure 1. Summary of cascading membrane damage induced by cold shock in ram spermatozoa stored at temperatures below $18^{\circ} \mathrm{C}$. Adapted from $[4,11]$. Created on Biorender.com.

Ram spermatozoa are highly susceptible to temperature changes, as they contain a low intramembrane cholesterol-to-phospholipid ratio compared to other species. In contrast to this, as seen in Table 2, boar spermatozoa can acquire partial resistance to cold shock during storage even though they have a low cholesterol-to-phospholipid ratio [30,31]. Bull spermatozoa are highly resistant to cold shock, as they contain the highest cholesterol-tophospholipid ratio of 0.45 [30]. The correlation between cold shock damage and cholesterolto-phospholipid ratio is further demonstrated within species, as boar spermatozoa with low and high membrane fluidity were correlated, respectively, with $38.8 \pm 2.5 \%$ and $26.8 \pm 3.2 \%$ cholesterol levels [32]. The extra intramembrane cholesterol protects against cold shock by supporting membrane stability [33]. It does this by limiting particle movement within the membrane during the cooling process, reducing membrane destabilisation events by $30 \%$ [32]. As ram spermatozoa have low cholesterol content and are therefore highly susceptible to cold shock damage, developing a semen preservation technique that aims to hold spermatozoa above cold-shock-inducing temperatures and provide extra membrane stability could preserve sperm quality for longer periods and make liquid storage at higher temperatures a more viable option for farmers.

Table 2. Summary of publications investigating semen storage temperatures between 20 and $37^{\circ} \mathrm{C}$ in various species.

\begin{tabular}{ccccc}
\hline Species & $\begin{array}{c}\text { Cholesterol } \\
\text { (mol \%) }\end{array}$ & $\begin{array}{c}\text { Ratio of Cholesterol: } \\
\text { Phospholipid }\end{array}$ & $\begin{array}{c}\text { Resistance to } \\
\text { Cold Shock }\end{array}$ & Reference \\
\hline Ram & 27 & 0.43 & Low & {$[34]$} \\
Bull & 31 & 0.45 & High & {$[35]$} \\
Stallion & Not reported & 0.36 & Low & {$[36]$} \\
Boar & Not reported & 0.37 & Partial & {$[37]$} \\
\hline
\end{tabular}

${ }^{1}$ Ratio of cholesterol to phospholipids from isolated plasma membrane fractions of spermatozoa.

\subsection{Concentration of Spermatozoa}

The recommended standard concentration for liquid ram spermatozoa storage at $23{ }^{\circ} \mathrm{C}$ is not fully defined as an international set standard, unlike frozen or chilled liquid storage $\left(5-15^{\circ} \mathrm{C}\right)[7,38]$. However, there have been many studies demonstrating the effects of high dilutions on spermatozoa, referred to as the dilution effect. The dilution effect 
occurs when spermatozoa undergo osmotic stress due to high dilution ratios, hypothesised to be related in part to a reduction in seminal plasma [39-41]. Gungdogen et al.'s, 2010 investigation demonstrated these consequences when ram spermatozoa were diluted to $100 \times 10^{6}$ sperm $/ \mathrm{mL}$ and recorded lower membrane damage and oxidative stress compared to spermatozoa diluted to $25 \times 10^{6}$ sperm $/ \mathrm{mL}$. Research has demonstrated this result in other species with various sperm concentrations, including rabbits [42], cattle [43,44], bucks [45], and pigs [46].

Research has identified various methods to reduce the dilution effect during semen preservation, one of which is slowing the dilution rate by using a step-wise dilution process and selecting suitable extenders. Step-wise dilutions allow spermatozoa time to osmotically balance with the changing external environment, preventing sudden osmotic stress $[7,41]$. By optimising extender ingredients and osmolarity, the spermatozoa's external environment is minimally altered [10]. Despite this knowledge, the exact mechanisms of the dilution effect in ram spermatozoa have not been fully elucidated, highlighting a knowledge gap within the semen preservation industry.

\subsection{Extenders}

Extenders are responsible for protecting and providing adequate resources to maintain sperm survival throughout the various stages of semen preservation. Extenders protect spermatozoa in many ways, including stabilising the plasma membrane and maintaining intracellular and intramembrane ionic concentrations, thus reducing cold shock damage and osmotic shock [1,47-50]. Extenders comprise diverse vital ingredients, allowing them to cater to species-specific requirements and the preservation method utilised.

Sperm cells are biologically different between species and thus require specific ingredients for protection. Furthermore, each species has a unique sperm $\mathrm{pH}$ tolerance zone where peak respiration is achieved [5,41]. For rams, this $\mathrm{pH}$ zone falls between 7.3 and 7.5, whereas bulls and cocks fall, respectively, between 6.5-7 and 6.9-7 [51]. These biological differences are not the only factor contributing to the different makeup of extenders, as each storage technique has particular stressors which sperm extenders must consider.

As such, extenders are specific to storage type depending on the key ingredients they contain. For example, Salamon's egg-yolk-based cryoprotectant contains glycerol to protect spermatozoa against ice crystal formation during the freezing process and uses glucose as a sugar source; however, Salamon's egg-yolk-based chilled extender does not contain glycerol and uses fructose [5], stimulating metabolism through a different pathway. Therefore, before storage at $23^{\circ} \mathrm{C}$ can be optimised, the current ram extenders and their ingredients should be examined for their ability to support sperm function at $23{ }^{\circ} \mathrm{C}$. Research must consider the major factors or features spermatozoa will require when held at higher temperatures to maximise fertility following storage.

\section{Key Extender Ingredients}

Standard in-house ram liquid extenders used to protect spermatozoa from changing temperatures, cold shock, and osmotic shock include Tris-citrate-fructose (TRIS), Salamon's egg-yolk-based extender (EY), and phosphate-buffered saline (PBS) [10]. Some key ingredients include phosphate-buffered saline, tris(hydroxymethyl)aminomethane (Tris), fructose, citric acid, egg yolk, bovine serum albumin (BSA), and various antibiotics. For example, BSA and Tris aid spermatozoa by acting as a protein source and a $\mathrm{pH}$ buffer [1], whereas fructose supplies sugars that provide crucial substrates for metabolism [26,52-54]. Additionally, citric acid acts as a $\mathrm{pH}$ buffer, maintaining peak respiration metabolic rates $[5,10]$, and egg yolk provides membrane support by supplying low-density lipoproteins (LDL) and cholesterol [33,52]. Finally, antibiotics including penicillin, streptomycin, and gentamycin aid spermatozoa by controlling bacterial growth [53]. Together, all these ingredients create liquid ram sperm extenders that can minimise the risk of any storage-related damages that compromise sperm quality. 
Currently, it is suggested that the primary storage-related damages for $23^{\circ} \mathrm{C}$ include oxidative stress and bacterial growth [12]. Therefore, the development of a ram-specific extender for $23^{\circ} \mathrm{C}$ needs to include key ingredients that not only preserve sperm quality but also provide extra support to reduce oxidative damage and bacterial growth.

\section{Changes to Spermatozoa during Liquid Preservation}

Despite ensuring the appropriate storage conditions during storage, it is common for spermatozoa to still incur some degree of osmotic, biochemical, and thermal stress [55]. These stressors force the cell to adapt and undergo a series of delicate conformational and metabolic changes. Most of these stressors cause membrane redistribution, lipid peroxidation, and impaired ATP production and motility (Figure 2 and Table 3). The following section will discuss these stressors, focusing on the resultant lipid peroxidation and its common occurrence following liquid storage at room temperature $\left(23^{\circ} \mathrm{C}\right)$.
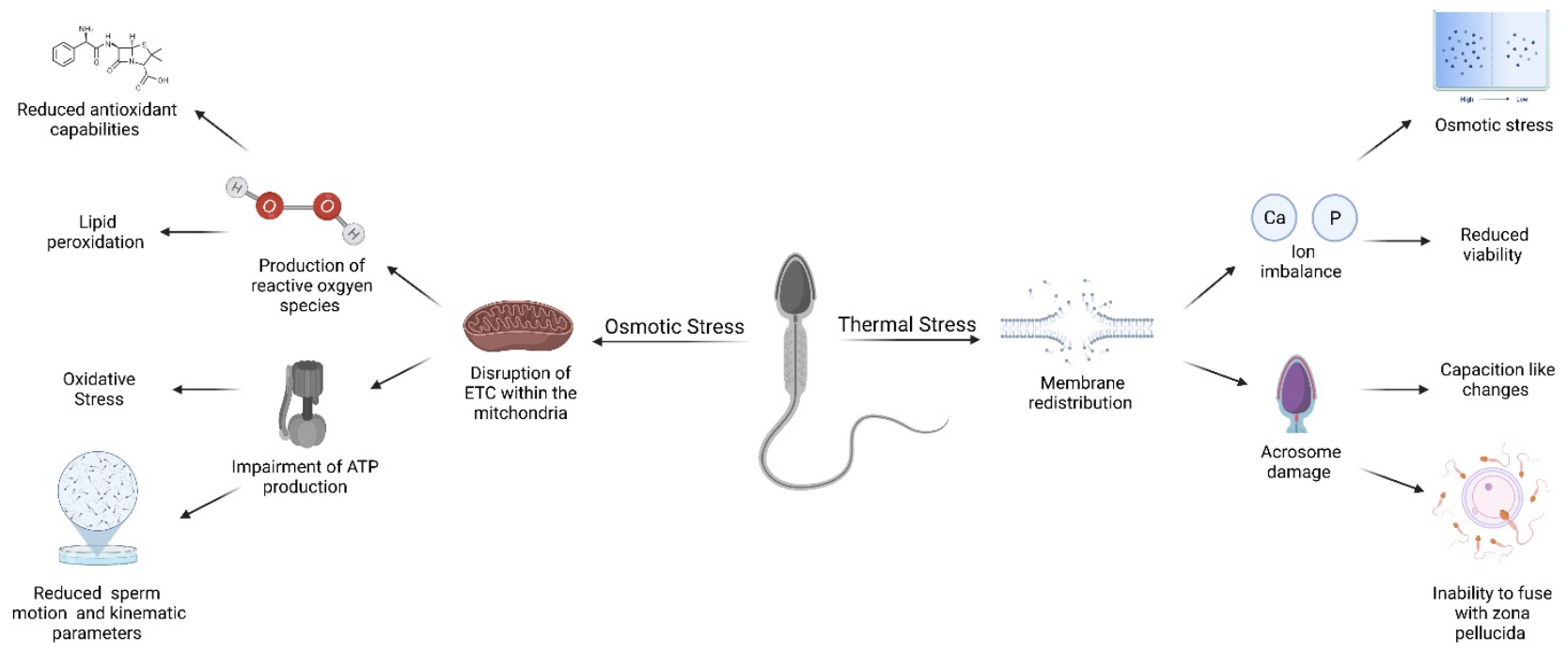

Figure 2. Summary of significant structural, functional, and molecular impairments incurred by ram spermatozoa cells undergoing osmotic and thermal stress inflicted by storing indefinitely via cryopreservation or temporarily chilled to $5-15^{\circ} \mathrm{C}$. Adapted from [1,4] and created on BioRender.com.

Table 3. Significant thermotropic phases and associated metabolic and physiological effects in the ram and boar spermatozoa.

\begin{tabular}{|c|c|c|c|}
\hline Phase Transition Temp & Species & Metabolic Changes & Physiological Changes \\
\hline \multirow[t]{2}{*}{$30-36^{\circ} \mathrm{C}^{*}$} & Ram & Intramembrane lipid scattering & Membrane fusogenicity \\
\hline & & Phosphate discontinuity & $\begin{array}{l}\text { Increased protein immobility and } \\
\text { reconfiguration }\end{array}$ \\
\hline \multirow[t]{2}{*}{$23-26{ }^{\circ} \mathrm{C}$} & Ram & Calcium transport discontinuity & ATPase activity reduced \\
\hline & & & $\begin{array}{c}\text { Intramembrane lipid scattering and } \\
\text { agglutination }\end{array}$ \\
\hline $23^{\circ} \mathrm{C}$ and $14^{\circ} \mathrm{C}$ & Boar & Reduction in $-\mathrm{CH}_{2}$ absorbance & $\begin{array}{l}\text { Inhibition of partial acquisition of cold shock } \\
\text { resistance }\end{array}$ \\
\hline $18^{\circ} \mathrm{C}$ & Boar & $40 \%$ increase in potassium efflux & Acceleration of ATPase \\
\hline \multirow[t]{2}{*}{$17^{\circ} \mathrm{C}$} & Ram & Intramembrane lipid scattering & $\begin{array}{c}\text { Membrane particle redistribution/aggregation } \\
\text { Ultrastructural freeze fractures }\end{array}$ \\
\hline & & Calcium influx & $\begin{array}{c}\text { Capacitation initiated } \\
\text { Irreversible membrane leakiness }\end{array}$ \\
\hline
\end{tabular}




\subsection{Membrane Redistribution}

A natural thermotropic transition involves the redistribution of intramembranous components to adapt to the surrounding environment [56]. This transition occurs during maturation or as a defence against reducing temperatures $[3,8]$. Throughout preservation, spermatozoa go from $37^{\circ} \mathrm{C}$ post ejaculation to $23^{\circ} \mathrm{C}$ for dilution and then to either $15{ }^{\circ} \mathrm{C}, 5{ }^{\circ} \mathrm{C}$, or $-196{ }^{\circ} \mathrm{C}$ for final storage [22]. Incorrect cooling procedures induce early thermotropic phases, leading to significant membrane damage. As seen in Table 3 , this damage includes a wide variety of consequences; however, it primarily includes membrane damage, such as protein reconfiguration and lipid agglutination, which creates irreversible particle-free zones known as ultrastructure freeze fractures [8].

Holt and North's 1986 study was one of the first to document thermotropic phases in rams. Ram spermatozoa displayed midpiece lipid agglutinations and acrosomal particlefree zones due to temperature-induced thermotropic phases [27]. This reconfiguration led to many ultrastructural and biochemical changes, presented in Table 3. These damages are similar in boars; however, due to higher cholesterol concentration, the intramembrane lipid agglutinations were localised around the head rather than the neck, as seen in rams [27]. Furthermore, bull spermatozoa demonstrated minimal particle-free zones or membrane redistribution [57]. These differences reflect the varying protecting nature of intramembrane cholesterol concentrations against cold shock, as rams, who have low intramembrane cholesterol, demonstrated more severe particle redistributions than bulls, which have a higher intramembrane cholesterol concentration. Particle-free zones are harmful to spermatozoa, as they contribute to membrane leakiness, encouraging an imbalance of homeostatic ions particularly heightened in rams (Table 3).

A direct consequence of particle-free zones is the disruption of homeostatic ion concentrations, leading to membrane collapse [58]. Disrupted ion balance is detrimental, as ions act as cellular signals responsible for initiating capacitation-like changes, disrupting metabolic pathways, and halting the overproduction of cytotoxic by-products [35,59]. As seen in Table 3, a harmful ionic event following cold shock in ram spermatozoa is the influx of calcium and efflux of phosphate at $17^{\circ} \mathrm{C}$ [58]. This event both stimulates the enzyme ATPase and reduces available intracellular phosphates, disrupting the mitochondrial electron transport chain, reducing ATP production, and increasing the frequency of escaped electrons, contributing to lipid peroxidation $[31,59,60]$. By understanding the changes associated with particle-free zones, extenders can be equipped to protect spermatozoa from these damages, primarily when held or maintained at higher temperatures.

The development of extenders and storage conditions have previously used the knowledge of thermotropic phases to accommodate the various stressors to which spermatozoa are subjected during semen preservation. For example, in rams, it was identified that intramembranous redistribution begins at a higher temperature during cooling due to low-cholesterol environments [58]. Therefore, adding cholesterol to an extender could reduce the damage incurred by colder temperatures, preserving motility and sperm quality for longer $[27,58]$. Furthermore, membrane redistribution can be significantly reduced if spermatozoa are stored above $17^{\circ} \mathrm{C}$ [58]. Therefore, research into methods of storing liquid ram spermatozoa at $23^{\circ} \mathrm{C}$ could reduce cold shock damages, preserving sperm function and quality for longer than $24 \mathrm{~h}$.

\subsection{Disruption of Respiration and Subsequent Decrease in Motility}

In rams, respiration, which powers motility, occurs via the mitochondrial electron transport chain (METC), fructolysis, or glycolysis [5,60-62]. METC yields a higher ATP per mol of glucose when compared to glycolysis, proving to be a more efficient process [63]. However, around $70 \%$ of all ATP consumption is used to power motility [64]

ATP production is impaired when incorrect storage conditions allow the METC to proceed unrestricted, eventually leading to the exhaustion of METC resources and dysfunction of the METC complexes of up to 75\% [62,64]. For example, the Bilodeau et al., 2002 study reported that excess hydrogen peroxide produced from incorrect storage and METC dys- 
function decreased ATP concentrations from $244 \pm 53 \mathrm{pmol} / 10^{6}$ cells and $4.83 \pm 1.08 \mu \mathrm{m}$ to $10 \pm 4 \mathrm{pmol} / 10^{6}$ cells and $2.80 \pm 0.99 \mu \mathrm{m}$ in bovine sperm following storage for $6 \mathrm{~h}$ at $38^{\circ} \mathrm{C}$.

Even though higher storage temperatures support motility, they can also exhaust energy resources, shortening overall lifespan. Therefore, by understanding how ATP production and motility are linked at higher temperatures, extenders could be built to maintain the mitochondrial METC while suppressing ROS production, allowing sperm to preserve motility.

\subsection{Lipid Peroxidation and Production of Reactive Oxygen Species}

Lipid peroxidation is one of the significant causes of sperm dysfunction following storage at $23{ }^{\circ} \mathrm{C}$. This process creates hydroperoxide intermediates and lipid peroxyl radicals through the oxidative degeneration of lipid metabolism [4,59]. Lipid peroxidation (Figure 3) contains three processes: initiation, propagation, and termination, which together contribute to sperm dysfunction $[4,15]$.

This section briefly summarises the biochemistry of lipid peroxidation and the significant effect of lipid peroxidation on ram sperm motility, viability, and acrosome integrity during storage at $23^{\circ} \mathrm{C}$.

\subsubsection{Lipid Peroxidation Biochemistry}

The first step of lipid peroxidation, initiation, involves free radicals breaking off allylic hydrogens within polyunsaturated fatty acids and forming carbon-centred lipid radicals $[4,65]$. As seen in Figure 3, the propagation step begins with the lipid radical combining with diatomic oxygen molecules and creating lipid peroxyl and hydroperoxyl radicals. It also involves the production of more polyunsaturated fatty acids, which goes on to repeat the initiation step, creating an autocatalytic, self-propagating reaction [65-67]. These two steps are where lipid peroxidation damage occurs, as initiation breaks down lipid membrane bilayers, and propagation produces lethal ROS, which directly inhibits the METC and oxidative phosphorylation [4]. The length of the initiation and propagation stages depends on the natural antioxidant capabilities of spermatozoa to initiate termination [4].

Antioxidants bring upon the final stage of lipid peroxidation, known as termination (Figure 3). They do this by neutralising radicals via the donation of hydrogen molecules to oxygen molecules and preventing further reactions [4]. As seen in Figure 3, termination can also be activated by radicals self-reacting and forming stable cytotoxic products such as malonaldehyde [68]. Future sections will extensively discuss natural and artificial antioxidants used in semen preservation to combat lipid peroxidation effects during storage at $23{ }^{\circ} \mathrm{C}$. 


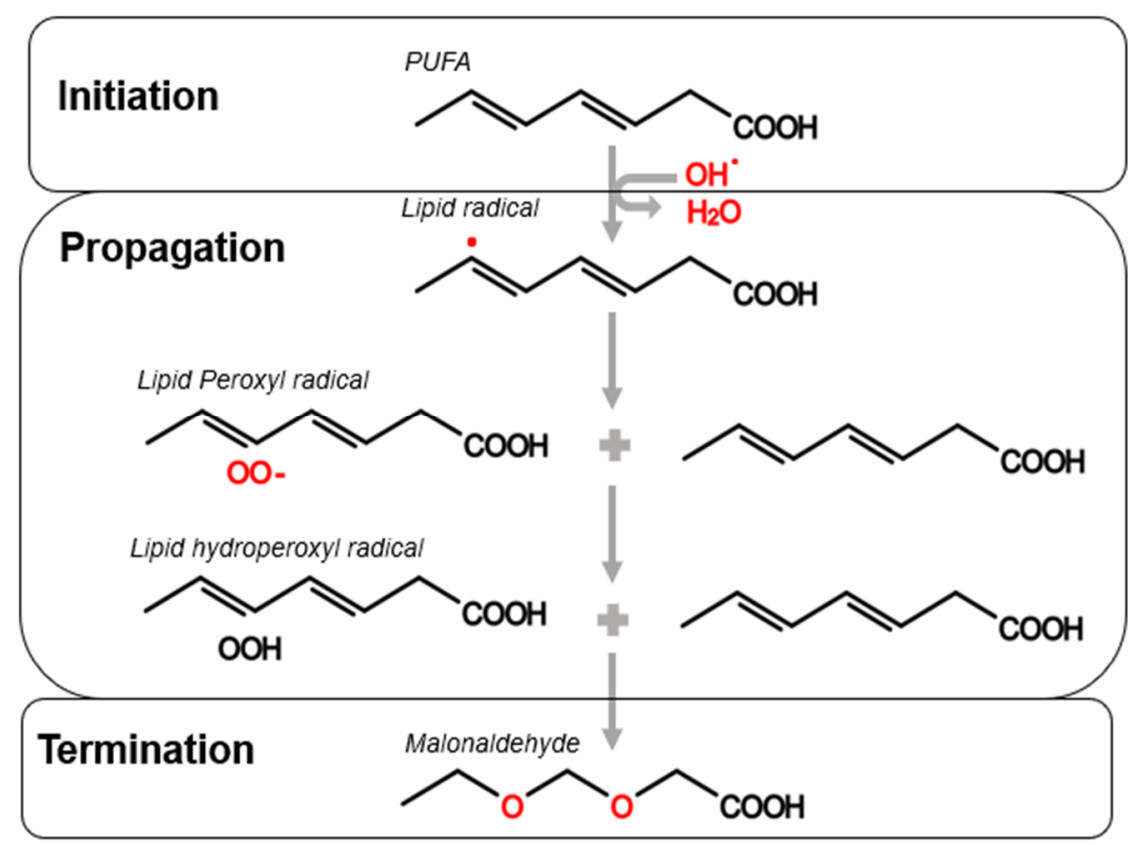

Figure 3. Summary of the three steps involved in lipid peroxidation: initiation, propagation, and termination. Adapted from $[13,67,69]$.

\subsubsection{Impact of Lipid Peroxidation on Sperm Function}

Motility and membrane integrity are significantly hindered by lipid peroxidation during $23{ }^{\circ} \mathrm{C}$ storage. Motility is hindered because ROS reconfigures METC enzymes, creating inefficiencies throughout the METC and increasing the frequency of electron leakiness $[65,66]$. An example of this occurring is 4-hydroxy-2-nonenal reacting with the mitochondrial protein succinic acid dehydrogenase [70]. This reaction changes the activation site of succinic acid from the carboxyl to the $\beta$ carbon, preventing it from undergoing catalyst reactions needed for oxidative phosphorylation [70]. This effect contributes to impaired motility by reducing ATP production and increasing escaped electrons that contribute to lipid peroxidation [66,67].

Lipid radicals favour high-polyunsaturated-lipid environments such as lipid bilayers. Membrane integrity and selective permeability are lost by radicals attacking the structure of membranes, inducing oxidative stress and unrestricted ion transport [69]. This combination impairs many sperm functions such as metabolism, motility, and fertility [71]. To protect themselves against the damaging effects of lipid peroxidation during $23^{\circ} \mathrm{C}$ storage, spermatozoa can utilise endogenous and exogenous antioxidants.

\subsubsection{Natural Defences to Reduce Lipid-Peroxidation-Induced Damage during Liquid Storage}

Spermatozoa are naturally provided with enzyme-based and non-enzyme-based antioxidants within the seminal plasma and harbour small intracellular antioxidants within the cytoplasm [44]. For example, enzyme-based antioxidants include catalase, glutathione S peroxidase (GSH peroxidase), and superoxide dismutase, whereas non-enzyme-based antioxidants can include cysteine vitamin $\mathrm{E}$ and methionine [4]. These antioxidants work concomitantly to neutralise radicals and prevent further oxidation reactions [72]. The protective ability of antioxidants relies on their concentration, as when an imbalance of antioxidants and ROS production occurs, lipid peroxidation begins [73].

In ram spermatozoa, glutathione-based antioxidants are higher in concentration than catalase and superoxide dismutase $[17,74]$. This concentration difference peaks during the breeding season, seen when Casco et al. (2010) recorded superoxide dismutase, catalase, and GSH peroxidase concentrations of $8.86 \pm 0.015 \mathrm{nmole} / \mathrm{min} . \mathrm{mL}$, $2.11 \pm 0.25 \mu \mathrm{mole} / \mathrm{min} . \mathrm{mL}$ and $61.57 \pm 4.48 \mathrm{nmole} / \mathrm{min} . \mathrm{mL}$, respectively, during the breed- 
ing season and $8.56 \pm 0.26$ mmole/min.mL, $1.74 \pm 0.19 \mu$ mole $/ \mathrm{min} . \mathrm{mL}$ and $52.86 \pm 8.53 \mathrm{nmole} /$ min.mL, respectively, during the non-breeding season. Furthermore, Hamilton et al.'s, 2016 study demonstrated a positive correlation between GSH peroxidase concentration and the rate of lipid peroxidation in chilled ram spermatozoa; however, the study found no correlation between superoxide dismutase or catalase and lipid peroxidation [74].

The protective abilities of natural antioxidants are not sufficient for storage at $23{ }^{\circ} \mathrm{C}$ due to the limited biosynthetic capacity of spermatozoa and diluted concentration of natural antioxidants $[4,75]$. Research into exogenous antioxidant supplementation to extenders can close the gap between antioxidants and ROS, protecting sperm from lipid peroxidation at $23{ }^{\circ} \mathrm{C}$ and making a viable alternative for storing ram spermatozoa [4].

\section{The Use of Antioxidant Supplementation to Attenuate Lipid Peroxidation Stress and Promote Liquid Spermatozoa Survival during Storage at $23{ }^{\circ} \mathrm{C}$}

Extenders are supplemented with exogenous antioxidants to resupply antioxidant defences against oxidative stress during storage at $23{ }^{\circ} \mathrm{C}$ [41]. Investigations into the advantages of supplying exogenous antioxidants to spermatozoa extenders have been successful in preserving sperm quality [76].

The advantages of exogenous antioxidants work in a dose- and temperature-dependent fashion [68,77]. For example, catalase illustrates dose dependency for rams, as $50 \mathrm{U} / \mathrm{mL}$ of catalase improved acrosome integrity, whereas 100-200 U/mL of catalase improved total motility, while $200 \mathrm{U} / \mathrm{mL}$ of catalase was cytotoxic to spermatozoa [73,78]. Maxwell and Stojanov's 1996 reports on temperature dependency showed that ram spermatozoa diluted with superoxide dismutase and catalase preserved greater motility at $15{ }^{\circ} \mathrm{C}$ when compared to $25^{\circ} \mathrm{C}$. Research into specific exogenous antioxidants for use in the ram to maximise survival during storage at $23{ }^{\circ} \mathrm{C}$ has not yet been fully elucidated and highlights a significant knowledge gap within the semen preservation industry.

Research into the pro-survival factors L-carnitine, pyruvate, and melatonin has shown promise in protecting spermatozoa at a wide variety of storage temperatures, including $23{ }^{\circ} \mathrm{C}$.

\subsection{L-Carnitine}

L-carnitine (LC) is a quaternary ammonium compound that acetylates into acetylL-carnitine (ALC) by the actions of carnitine acyltransferase 1 [79-83]. LC's primary responsibility is to facilitate the transport of exogenous fatty acyl-CoA across the mitochondrial matrix [80]. In comparison, ALC acts as a readily oxidizable energy source for respiration as well as a buffer for acetyl-CoA transportation [79-83]. Both molecules are vital for the maintenance of metabolic processes such as motility.

Previous research has demonstrated that these roles improve the motility of sperm stored at higher temperatures in species such as boars [84], bucks [85], stallions [55], bovines [86], and rams [87] (Table 4). LC protects sperm motility mainly by sustaining METC, ATP production, and membrane integrity while providing antioxidant defences during storage [58]. For example, after ten days of storage, $50 \mathrm{mM}$ of LC added to boar spermatozoa stored at $17{ }^{\circ} \mathrm{C}$ had increased motility, mitochondrial activity, and ATP production, as well as antioxidant capacity [84]. Despite this success, some studies, such as Deana et al. (1989) (Table 4), demonstrated that the addition of $20 \mathrm{mM}$ LC can be harmful to bovine sperm spermatozoa, while the addition of $20 \mathrm{mM}$ of LC or ALC at either $5{ }^{\circ} \mathrm{C}$, $20{ }^{\circ} \mathrm{C}$, or $37^{\circ} \mathrm{C}$ storage maintained $80 \%$ viability but increased intracellular calcium by $24 \%$, which decreased progressive motility and oxygen consumption after 24 min (Table 4) [86]. These results were strongly correlated with higher temperatures, as extracellular LC or ALC uptake was demonstrated to be higher at $37^{\circ} \mathrm{C}$ and $20^{\circ} \mathrm{C}$ when compared to $5^{\circ} \mathrm{C}$ [86]. There is reason to investigate LC's other beneficial or inhibitory effects on ram spermatozoa, particularly its antioxidant ability at $23^{\circ} \mathrm{C}$. 
Table 4. Summary of noteworthy results on the supplementation of L-carnitine (LC) to spermatozoa during storage above $5{ }^{\circ} \mathrm{C}$ in various species.

\begin{tabular}{ccccc}
\hline Species & Temp $\left({ }^{\circ} \mathbf{C}\right)$ & Extender & Result & Reference \\
\hline Boar & 17 & Androhep & $\begin{array}{c}\text { Higher membrane integrity at } 50 \mathrm{mM} \text { when compared } \\
\text { to } 12.5 \mathrm{mM}, 25 \mathrm{mM} \text {, and } 100 \mathrm{mM} \text { at ten days }\end{array}$ \\
\hline Ram & 5 & Skimmed milk extender & $\begin{array}{c}\text { Higher } \mathrm{TM} \text { at } 10 \mathrm{mM} \text { when compared to } 1 \mathrm{mM}, \\
2.5 \mathrm{mM}, 5 \mathrm{mM} \text {, and } 7.5 \mathrm{mM} \text { at } 96 \mathrm{~h}\end{array}$ \\
\hline Stallions & 23 & MBWW & Higher MMP $(\%)$ at $0 \mathrm{mM}$ than at $10 \mathrm{mM}$ at $72 \mathrm{~h}$ & [55] \\
\hline & & Higher PM at $0 \mathrm{mM}$ when compared to $10 \mathrm{mM}$ at $72 \mathrm{~h}$ \\
\hline
\end{tabular}

Higher ROS at $0 \mathrm{mM}$ when compared to $10 \mathrm{mM}$ at $72 \mathrm{~h}$

$\begin{array}{ccccc} & 5 & & \text { Lower PM at } 20 \mathrm{mM} \mathrm{LC} \text { and } 20 \mathrm{mM} \text { ALC when } \\ \text { Bovine } & 20 & \text { Sodium chlorine extender } & \text { [86] }\end{array}$

MMP = mitochondrial membrane potential and MBWW = modified Biggers, Whitten, and Whittingham.

LC and ALC act as antioxidants by forming a part of a negative feedback loop with the METC, which reduces radical synthesis and lipid peroxidation [83]. Recent investigations into LC support this, as the addition of $7.5 \mathrm{mM}$ LC reduced ROS production by $40-60 \%$ in liquid stallion spermatozoa following storage at $23{ }^{\circ} \mathrm{C}$ [55]. Furthermore, presented in Table 4, $7.5 \mathrm{mM}$ of LC maintained membrane intactness in ram spermatozoa stored at $15{ }^{\circ} \mathrm{C}$ for $96 \mathrm{~h}$ [88]. Further details of studies which have investigated the use of LC in preserving sperm functionality during liquid storage are presented in Table 4 . These studies indicate that $10 \mathrm{mM}$ of LC could potentially be the optimal supplementation concentration; however, future research is needed to confirm this. Although previously researched for cryopreserved ram spermatozoa [89], the effect of LC and ALC as an antioxidant protecting ram spermatozoa against lipid peroxidation when stored at $23{ }^{\circ} \mathrm{C}$ has not been thoroughly investigated, highlighting a significant knowledge gap in higher-temperature semen preservation.

\subsection{Pyruvate}

Pyruvate sustains the quality of liquid-stored spermatozoa by maintaining the efficiency of the metabolic pathways [63]. Pyruvate supplies metabolic pathways by transforming into the metabolic intermediates acetyl-CoA, malate, and oxaloacetate $[90,91]$. The functioning of these processes is crucial to maintaining motility during liquid storage [90]. Studies have demonstrated this by utilising antimycin A to inhibit human spermatozoa's metabolic functioning and motility [61]. With the addition of pyruvate to these inhibited pathways, ATP production and progressive motility increased by $56 \%$ and $21 \%$, respectively [91]. In addition, stallion spermatozoa stored at $23{ }^{\circ} \mathrm{C}$ for $72 \mathrm{~h}$ demonstrated that $10 \mathrm{mM}$ of pyruvate increased the total motility of spermatozoa from $18.9 \pm 1.4 \%$ in control to $26.1 \pm 1.7 \%$ [55]. Apart from increasing motility, pyruvate also reduces electron leakage and prevents the onset of lipid peroxidation, thereby giving it antioxidant qualities [92]. For example, as seen in Table 5, Ortiz-Rodríguez et al. (2021) supplemented stallion spermatozoa with pyruvate and stored it at $18{ }^{\circ} \mathrm{C}$ for $48 \mathrm{~h}$. They demonstrated an increase in mitochondrial activity from $24.1 \pm 1.8 \%$ in the control to $51.1 \pm 0.7 \%$ in high-pyruvate media while maintaining $76.2 \pm 1 \%$ viability, reducing ROS from $64.3 \pm 1.3 \%$ to $45.4 \pm 4.7 \%$, and increasing GSH concentration from 10,162 \pm 731.7 to $15,553 \pm 912$.

Pyruvate reduces the onset of lipid peroxidation and ROS production during liquid storage by behaving as both a direct and indirect antioxidant [93]. Pyruvate can directly interact as an antioxidant due to the reactive keto-enol within its conformation [94]. This architecture allows pyruvate to directly neutralise peroxides and peroxynitrites in a non- 
enzymatical redox reaction without producing cytotoxic oxygen radicals [95]. Furthermore, pyruvate can indirectly stimulate the glutathione pathway through glutathione reductase production [63]. Furthermore, in Table 5, Gibb et al.'s, 2015 study demonstrated that stallion spermatozoa stored at $25^{\circ} \mathrm{C}$ and supplemented with $10 \mathrm{mM}$ of pyruvate had reduced lipid peroxidation levels after $72 \mathrm{~h}$.

Table 5. Summary of noteworthy results on pyruvate supplementation to semen storage above $5{ }^{\circ} \mathrm{C}$ in various species.

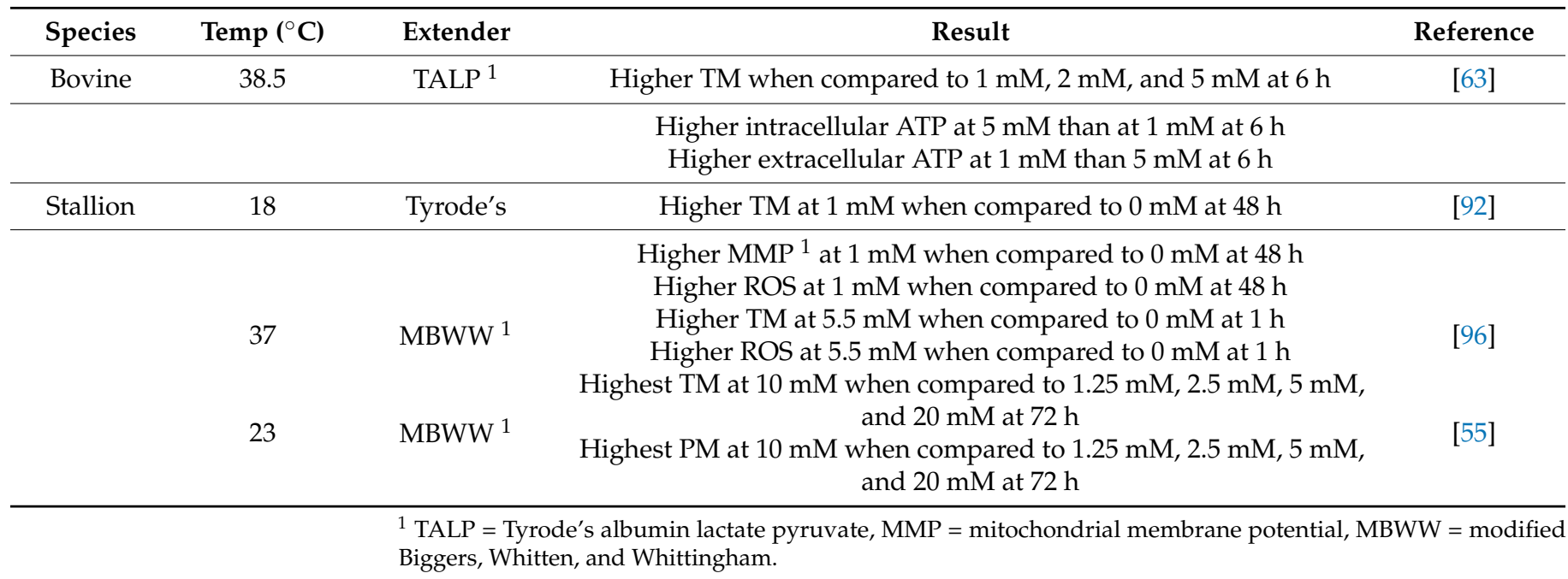

The benefit of pyruvate during chilled sperm storage has been well-documented (Table 5); however, limited research into its use during higher-temperature storage shows pyruvate's ability to reduce the onset of lipid peroxidation and ROS production in rams at $10 \mathrm{mM}$. Therefore, further research into pyruvate's protective ability at $23^{\circ} \mathrm{C}$ is crucial for developing liquid ram sperm-specific extenders for the industry.

\subsection{Melatonin (N-Acetyl-5-Methoxytryptamine)}

Melatonin is acclaimed for its role in circadian rhythm; however, it is growing in popularity as a mitochondrial-targeted antioxidant due to its scavenging abilities and indirect role in stimulating antioxidant gene expression [17]. Melatonin's success in preventing lipid peroxidation is attributed to its antioxidant radical scavenging abilities [97]. Melatonin's scavenging abilities are unique, as they differ depending on the dosage supplemented to spermatozoa and the type of ROS it interacts with (Table 6) [98-100]. For example, melatonin neutralises hydroxyl radicals $(\mathrm{OH})$ by transforming them into stable metabolites [101]. A reduced lipid peroxidation level was demonstrated in boars when melatonin reduced malondialdehyde (MDA) levels from $17.5 \mathrm{nmol} / 1 \times 10^{6}$ to $12 \mathrm{nmol} / 1 \times 10^{6}$ [98]. Similar trends were reported in bulls, as $7 \mathrm{mM}$ of MDA was produced in melatoninsupplemented treatments compared with $11.7 \mathrm{mM}$ MDA produced in the control [102]. Unlike hydroxyl, melatonin does not undergo a direct redox reaction with nitric oxide [91]. Here, melatonin binds with $\mathrm{Ca}^{2+}$ and calmodulin, nitric oxide production components, via the eNOS-dependant nitric oxide production pathway [103]. Previous research in rams has demonstrated the benefits of melatonin's unique scavenging abilities [104]. For example, Casco et al.'s, 2010 investigation concluded that ram spermatozoa supplied with melatonin stored at $39^{\circ} \mathrm{C}$ for $3 \mathrm{~h}$ demonstrated decreased capacitation and apoptotic-like changes. Previous research into the effects of melatonin during storage in different species is extensively summarised in Table 6, including rams [20], boars [105], and buffalo [19]. Furthermore, new research has also demonstrated that melatonin plays a role in preserving fertility, as natural melatonin concentration ranges from $137.51 \pm 17.8 \mathrm{pg} / \mathrm{mL}$ in the breeding season to $46.57 \pm 8.37$ throughout the non-breeding season $[17,106]$. 
Table 6. Summary of noteworthy results on melatonin supplementation (Mel) for semen storage above $5{ }^{\circ} \mathrm{C}$ in various species.

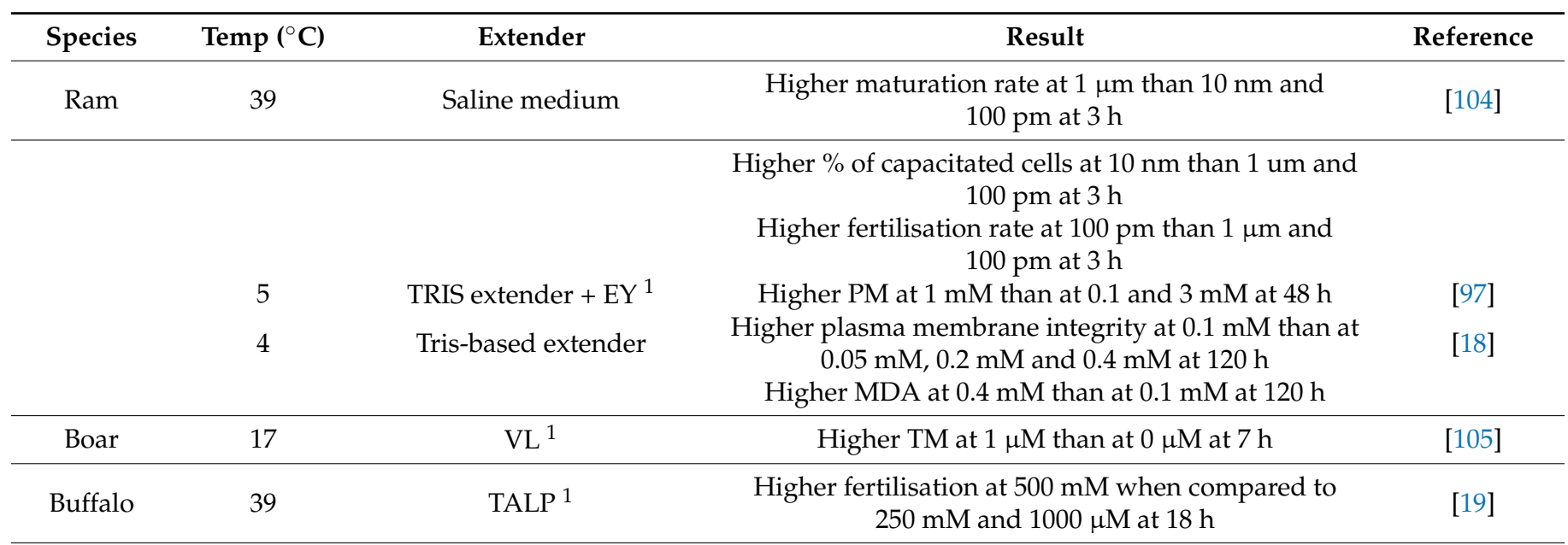

Higher TM at $50 \mathrm{pm}$ when compared to $100 \mathrm{pm}$, $200 \mathrm{pm}$ and $1 \mu \mathrm{m}$ at $18 \mathrm{~h}$

${ }^{1} \mathrm{VL}=$ Vitasem LD Magapor, Zaragoza, Spain, EY = egg yolk, MMP = mitochondria membrane potential $\mathrm{SM}=$ skim milk, TALP $=$ Tyrode's albumin lactate pyruvate.

Previous investigations into melatonin for semen preservation of various species at $23{ }^{\circ} \mathrm{C}$ have shown considerable promise in preserving sperm quality for longer than $24 \mathrm{~h}$; however, research is limited for rams, especially at $10 \mathrm{mM}$. Therefore, investigations into the protective ability of melatonin during $23^{\circ} \mathrm{C}$ storage are necessary.

\section{Conclusions}

Semen preservation is a vital artificial reproductive technology, enabling producers to take advantage of the benefits from genetically superior sires. Despite significant developments in preservation methods and extenders, as a result of being subjected to reduced temperatures, the process can still inflict sub-lethal damage to spermatozoa, including integral membrane protein agglutination, altered protein functions, and loss of selective membrane permeability.

The storage of spermatozoa at ambient temperature removes the risk of thermal damage caused by cold shock. It has shown success in maintaining the motility and viability of spermatozoa from a variety of species, including stallions [107], humans [108], mice [109], and bulls [110]. Several studies have investigated the ability of ram spermatozoa to survive storage at $23{ }^{\circ} \mathrm{C}$; however, it has yet to be comparable to current industry methods, and the increased threat of lipid peroxidation and ROS production could significantly hinder fertility post storage.

Ongoing research has shown promising results using exogenous antioxidants such as L-carnitine, melatonin, and pyruvate to combat damage caused by lipid peroxidation. However, limited research has investigated the ability of these antioxidants to protect ram spermatozoa when stored at $23^{\circ} \mathrm{C}$. It would therefore be prudent to not only assess the function of ram spermatozoa following storage at $23{ }^{\circ} \mathrm{C}$ when supplemented with the above-mentioned pro-survival factors, but also compare the rates of lipid peroxidation to those produced following preservation at $5{ }^{\circ} \mathrm{C}$ and cryopreservation. If liquid storage at $23{ }^{\circ} \mathrm{C}$ is to be successful and widely adopted amongst the industry, it needs to reduce the rates of lipid peroxidation compared to other methods of semen preservation and record higher levels of fertility, specifically for artificial insemination.

If ram sperm functionality and fertility could be maintained following storage longer than $24 \mathrm{~h}$ at $23^{\circ} \mathrm{C}$, this would provide an alternative sperm storage option for producers when they want to take advantage of genetics from superior sires located vast distances 
from the insemination site. It would also offer producers an alternative to freezing spermatozoa, reducing the risk of sub-lethal damage and enabling the use of non-surgical artificial insemination methods such as cervical artificial insemination.

Author Contributions: Main Author and Writing-Original Draft Preparation, N.R.; Methodology, Writing-Review and Editing, and Supervision, J.P.R., C.G.C., and S.P.d.G. All authors have read and agreed to the published version of the manuscript.

Funding: This research received no external funding. Jessica Rickard was supported by the McCaughey Memorial Institute.

Institutional Review Board Statement: Not applicable.

Informed Consent Statement: Not applicable.

Data Availability Statement: Not applicable.

Acknowledgments: The authors acknowledge the support and technical assistance provided by members of the Animal Reproduction Group at the University of Sydney as well as members of the Sydney Informatics Hub, University of Sydney.

Conflicts of Interest: The authors declare no conflict of interest.

\section{References}

1. Salamon, S.; Maxwell, W.M.C. Storage of Ram Semen. Anim. Reprod. Sci. 2000, 62, 77-111. [CrossRef]

2. Brinsko, S.P. Insemination Doses: How Low Can We Go? Theriogenology 2006, 66, 543-550. [CrossRef] [PubMed]

3. Gillan, L.; Maxwell, W.M.C.; Evans, G. Preservation and Evaluation of Semen for Artificial Insemination. Reprod. Fertil. Dev. 2004, 16, 447-454. [CrossRef]

4. Kameni, S.L.; Meutchieye, F.; Ngoula, F. Liquid Storage of Ram Semen: Associated Damages and Improvement. Open J. Anim. Sci. 2021, 11, 473-500. [CrossRef]

5. Evans, G.; Maxwell, W.M.C. Salamon's Artifical Insemination of Sheep and Goats; Butterworth Pty Limited: Tennant Creek, Australia, 1987.

6. Pini, T.; Leahy, T.; De Graaf, S.P. Sublethal Sperm Freezing Damage: Manifestations and Solutions. Theriogenology 2018, 118, 172-181. [CrossRef]

7. Salamon, S.; Maxwell, W.M.C. Frozen Storage of Ram Semen I. Processing, Freezing, Thawing and Fertility after Cervical Insemination. Anim. Reprod. Sci. 1995, 37, 185-249. [CrossRef]

8. White, I. Lipids and Calcium Uptake of Sperm in Relation to Cold Shock and Preservation: A Review. Reprod. Fertil. Dev. 1993, 5, 639. [CrossRef] [PubMed]

9. Salamon, S.; Maxwell, W.M.C. Frozen Storage of Ram Semen II. Causes of Low Fertility after Cervical Insemination and Methods of Improvement. Anim. Reprod. Sci. 1995, 38, 1-36. [CrossRef]

10. Maxwell, W.M.; Salamon, S. Liquid Storage of Ram Semen: A Review. Reprod. Fertil. Dev. 1993, 5, 613-638. [CrossRef]

11. Sathe, S.R. Laparoscopic Artificial Insemination Technique in Small Ruminants-A Procedure Review. Front. Vet. Sci. 2018, 5, 266. [CrossRef] [PubMed]

12. Wusiman, A.; Wang, Y.-P.; Ren, K.; Zhou, G.-B.; Fu, X.-W.; Suo, L.; Fan, Z.-Q.; Wang, L.; Zhu, S.-E. Semen Storage at 23, 4 or -196c and Its Applications to Artifical Inseminatio in Small-Tail Han Sheep. Asian J. Anim. Vet. Adv. 2012, 7, 299-308. [CrossRef]

13. Borza, C.; Muntean, D.; Dehelean, C.; Savoiu, G.; Serban, C.; Simu, G.; Andoni, M.; Butur, M.; Drag, S. Oxidative Stress and Lipid Peroxidation-A Lipid Metabolism Dysfunction; InTech: Rijeka, Croatia, 2013.

14. Aitken, R.J.; Gibb, Z.; Baker, M.A.; Drevet, J.; Gharagozloo, P. Causes and Consequences of Oxidative Stress in Spermatozoa. Reprod. Fertil. Dev. 2016, 28, 1-10. [CrossRef]

15. Aitken, R.J.; Baker, M.A. Oxidative Stress, Sperm Survival and Fertility Control. Mol. Cell. Endocrinol. 2006, 250, 66-69. [CrossRef]

16. Bruemmert, J.E.; Coy, R.C.; Squires, E.L.; Graham, J.K. Effect of Pyruvate on the Function of Stallion Spermatozoa Stored for up to 48 Hours1. J. Anim. Sci. 2002, 80, 12-18. [CrossRef] [PubMed]

17. Casao, A.; Cebrián, I.; Asumpção, M.E.; Pérez-Pé, R.; Abecia, J.A.; Forcada, F.; Cebrián-Pérez, J.A.; Muiño-Blanco, T. Seasonal Variations of Melatonin in Ram Seminal Plasma Are Correlated to Those of Testosterone and Antioxidant Enzymes. Reprod. Biol. Endocrinol. 2010, 8, 1-9. [CrossRef]

18. Dai, G.-C.; Meng, Y.; Zhang, L.-K.; Du, Y.-Q.; Wen, F.; Feng, T.-Y.; Hu, J.-H. Effect of Addition of Melatonin on Liquid Storage of Ram Semen at $4{ }^{\circ} \mathrm{C}$. Andrologia 2019, 51, e13236. [CrossRef] [PubMed]

19. Nagina, G.; Asima, A.; Nemat, U.; Shamim, A. Effect of Melatonin on Maturation Capacity and Fertilization of Nili-Ravi Buffalo (Bubalus Bubalis) Oocytes. Open Vet. J. 2016, 6, 128-134. [CrossRef] [PubMed]

20. Paulenz, H.; Söderquist, L.; Pérez-Pé, R.; Berg, K.A. Effect of Different Extenders and Storage Temperatures on Sperm Viability of Liquid Ram Semen. Theriogenology 2002, 57, 823-836. [CrossRef] 
21. Kaabi, M.; Paz, P.; Alvarez, M.; Anel, E.; Boixo, J.C.; Rouissi, H.; Herraez, P.; Anel, L. Effect of Epididymis Handling Conditions on the Quality of Ram Spermatozoa Recovered Post-Mortem. Theriogenology 2003, 60, 1249-1259. [CrossRef]

22. Alomar, M.; Zarkawi, M.; Alzoabi, M.A. Analysis of Awassi Sperm Motility in Two Media at Different Levels of Temperature, PH and Osmolality. Iran. J. Appl. Anim. Sci. 2018, 8, 431-438.

23. Murphy, E.M.; Murphy, C.; O'Meara, C.; Dunne, G.; Eivers, B.; Lonergan, P.; Fair, S. A Comparison of Semen Diluents on the in Vitro and in Vivo Fertility of Liquid Bull Semen. J. Dairy Sci. 2017, 100, 1541-1554. [CrossRef] [PubMed]

24. Qiu, J.-H.; Li, Y.-W.; Xie, H.-L.; Li, Q.; Dong, H.-B.; Sun, M.-J.; Gao, W.-Q.; Tan, J.-H. Effects of Glucose Metabolism Pathways on Sperm Motility and Oxidative Status during Long-Term Liquid Storage of Goat Semen. Theriogenology 2016, 86, 839-849. [CrossRef] [PubMed]

25. Cuervo-Arango, J.; Nivola, K.; Väihkönen, L.; Katila, T. The Effect of Storage Temperature of Stallion Semen on Pregnancy Rates. J. Equine Vet. Sci. 2015, 35, 611-616. [CrossRef]

26. Province, C.A.; Squires, E.L.; Pickett, B.W.; Amann, R.P. Cooling Rates, Storage Temperatures and Fertility of Extended Equine Spermatozoa. Theriogenology 1985, 23, 925-934. [CrossRef]

27. Holt, W.V.; North, R.D. Partially Irreversible Cold-Induced Lipid Phase Transitions in Mammalian Sperm Plasma Membrane Domains: Freeze-Fracture Study. J. Exp. Zool. 1984, 230, 473-483. [CrossRef] [PubMed]

28. Watson, P.F. The Causes of Reduced Fertility with Cryopreserved Semen. Anim. Reprod. Sci. 2000, 60-61, 481-492. [CrossRef]

29. Maxwell, W.M.C.; Johnson, L.A. Membrane Status of Boar Spermatozoa after Cooling or Cryopreservation. Theriogenology 1997, 48, 209-219. [CrossRef]

30. Blackshaw, A.W. The Prevention of Temperature Shock of Bull and Ram Semen. Aust. J. Biol. Sci. 1954, 7, 573-582. [CrossRef]

31. Pursel, V.G.; Johnson, L.A.; Schulman, L.L. Effect of Dilution, Seminal Plasma and Incubation Period on Cold Shock Susceptibility of Boar Spermatozoa. J. Anim. Sci. 1973, 37, 528-531. [CrossRef] [PubMed]

32. Flesch, F.M.; Brouwers, J.F.H.M.; Nievelstein, P.; Verkleij, A.J.; van Golde, L.M.G.; Colenbrander, B.; Gadella, B.M. Bicarbonate Stimulated Phospholipid Scramblinginduces Cholesterol Redistribution and Enablescholesterol Depletion in the Sperm Plasma Membrane. J. Cell Sci. 2001, 114, 3543-3555. [CrossRef] [PubMed]

33. Kessel, A.; Ben-Tal, N.; May, S. Interactions of Cholesterol with Lipid Bilayers: The Preferred Configuration and Fluctuations. Biophys. J. 2001, 81, 643-658. [CrossRef]

34. Cross, N.L. Role of Cholesterol in Sperm Capacitation1. Biol. Reprod. 1998, 59, 7-11. [CrossRef] [PubMed]

35. Parks, J.E.; Lynch, D.V. Lipid Composition and Thermotropic Phase Behavior of Boar, Bull, Stallion, and Rooster Sperm Membranes. Cryobiology 1992, 29, 255-266. [CrossRef]

36. Moore, A.I.; Squires, E.L.; Graham, J.K. Adding Cholesterol to the Stallion Sperm Plasma Membrane Improves Cryosurvival. Cryobiology 2005, 51, 241-249. [CrossRef] [PubMed]

37. Labbé, C.; Bussière, J.-F.; Guillouet, P.; Leboeuf, B.; Magistrini, M. Cholesterol/Phospholipid Ratio in Sperm of Several Domestic Species Does Not Directly Predict Sperm Fitness for Cryopreservation. Genet. Sel. Evol. 2001, 33, S61. [CrossRef]

38. Peker akalin, P.; Bucak, M.N.; Güngör, Ş.; Başpinar, N.; Çoyan, K.; Dursun, Ş.; İli, P.; Aksoy, A.; Karaşör, Ö.F.; Bilgili, A.; et al. Influence of Lycopene and Cysteamine on Sperm and Oxidative Stress Parameters during Liquid Storage of Ram Semen at $5{ }^{\circ} \mathrm{C}$ Small Rumin. Res. 2016, 137, 117-123. [CrossRef]

39. Maxwell, W.M.C.; Johnson, L.A. Physiology of Spermatozoa at High Dilution Rates: The Influence of Seminal Plasma. Theriogenology 1999, 52, 1353-1362. [CrossRef]

40. Harrison, R.a.P.; Dott, H.M.; Foster, G.C. Bovine Serum Albumin, Sperm Motility, and the “Dilution Effect”. J. Exp. Zool. 1982, 222, 81-88. [CrossRef]

41. Leahy, T.; Marti, J.I.; Mendoza, N.; Pérez-Pé, R.; Muiño-Blanco, T.; Cebrián-Pérez, J.A.; Evans, G.; Maxwell, W.M.C. High Pre-Freezing Dilution Improves Post-Thaw Function of Ram Spermatozoa. Anim. Reprod. Sci. 2010, 119, 137-146. [CrossRef]

42. Castellini, C.; Lattaioli, P.; Moroni, M.; Minelli, A. Effect of Seminal Plasma on the Characteristics and Fertility of Rabbit Spermatozoa. Anim. Reprod. Sci. 2000, 63, 275-282. [CrossRef]

43. Garner, D.L.; Thomas, C.A.; Gravance, C.G.; Marshall, C.E.; DeJarnette, J.M.; Allen, C.H. Seminal Plasma Addition Attenuates the Dilution Effect in Bovine Sperm. Theriogenology 2001, 56, 31-40. [CrossRef]

44. Patil, S.; Kumar, P.; Singh, G.; Bala, R.; Jerome, A.; Patil, C.S.; Kumar, D.; Singh, S.; Sharma, R.K. 'Semen Dilution Effect' on Sperm Variables and Conception Rate in Buffalo. Anim. Reprod. Sci. 2020, 214, 106304. [CrossRef] [PubMed]

45. Sadeghi, S.; Gallego, R.D.; Garcia-Colomer, B.; Gomez, E.A.; Yaniz, J.; Gosalvez, J.; Lopez- Fernandez, C.; Silvestre, M.A. Effect of Sperm Concentration and StorageTemperature on Goat Spermatozoa DuringLiquid Storage. Biology 2020, 9, 300. [CrossRef] [PubMed]

46. Caballero, I.; Vázquez, J.M.; García, E.M.; Roca, J.; Martínez, E.A.; Calvete, J.J.; Sanz, L.; Ekwall, H.; Rodríguez-Martínez, H. Immunolocalization and Possible Functional Role of PSP-I/PSP-II Heterodimer in Highly Extended Boar Spermatozoa. J. Androl. 2006, 27, 766-773. [CrossRef]

47. Forouzanfar, M.; Sharafi, M.; Hosseini, S.M.; Ostadhosseini, S.; Hajian, M.; Hosseini, L.; Abedi, P.; Nili, N.; Rahmani, H.R.; Nasr-Esfahani, M.H. In Vitro Comparison of Egg Yolk-Based and Soybean Lecithin-Based Extenders for Cryopreservation of Ram Semen. Theriogenology 2010, 73, 480-487. [CrossRef]

48. Albiaty, N.M.H.; Alobaidi, H.J.K.; Kareem, A.F.; Al-Hakim, A.M.; Alnaed, A.; Alkhazraji, A.A.H. Effect of Extenders and Preservation Periods in Some Semen Characteristics of Awassi Ram. World J. Pharm. Res. 2016, 5, 234-243. 
49. Arando, A.; Delgado, J.V.; León, J.M.; Nogales, S.; Navas-González, F.J.; Pizarro, M.G.; Pérez-Marín, C.C. Effect of Three Commercial Extenders on Sperm Motility and Fertility in Liquid Ram Semen Stored at $15^{\circ} \mathrm{C}$ or $5{ }^{\circ} \mathrm{C}$. Acta Vet. Hung. 2019, 67, 430-444. [CrossRef]

50. Arando, A.; Gonzalez, A.; Delgado, J.V.; Arrebola, F.A.; Perez-Marín, C.C. Storage Temperature and Sucrose Concentrations Affect Ram Sperm Quality after Vitrification. Anim. Reprod. Sci. 2017, 181, 175-185. [CrossRef] [PubMed]

51. Stojanov, T. Studies on the Liquid Storage of Ram Spermatozoa in the Presnce or Absence of Antioxidants. Ph.D. Thesis, University of Sydney, Sydney, Australia, 1995.

52. Bergeron, A.; Crête, M.-H.; Brindle, Y.; Manjunath, P. Low-Density Lipoprotein Fraction from Hen's Egg Yolk Decreases the Binding of the Major Proteins of Bovine Seminal Plasma to Sperm and Prevents Lipid Efflux from the Sperm Membrane1. Biol. Reprod. 2004, 70, 708-717. [CrossRef]

53. Yaniz, J.; Marco-Aguado, M.-A.; Mateos, J.A.; Santolaria, P. Bacterial Contamination of Ram Semen, Antibiotic Sensitivities, and Effects on Sperm Quailty during Storage at 15c. Anim. Reprod. Sci. 2010, 122, 142-149. [CrossRef] [PubMed]

54. Sawyer, D.E.; Mercer, B.G.; Wiklendt, A.M.; Aitken, R.J. Quantitative Analysis of Gene-Specific DNA Damage in Human Spermatozoa. Mutat. Res. Mol. Mech. Mutagen. 2003, 529, 21-34. [CrossRef]

55. Gibb, Z.; Lambourne, S.R.; Quadrelli, J.; Smith, N.D.; Aitken, R.J. L-Carnitine and Pyruvate Are Prosurvival Factors during the Storage of Stallion Spermatozoa at Room Temperature. Biol. Reprod. 2015, 93, 104. [CrossRef] [PubMed]

56. Drobnis, E.Z.; Crowe, L.M.; Berger, T.; Anchordoguy, T.J.; Overstreet, J.W.; Crowe, J.H. Cold Shock Damage Is Due to Lipid Phase Transitions in Cell Membranes: A Demonstration Using Sperm as a Model. J. Exp. Zool. 1993, 265, 432-437. [CrossRef] [PubMed]

57. Leeuw, F.E.D.; Chen, H.-C.; Colenbrander, B.; Verkleij, A.J. Cold-Induced Ultrastructural Changes in Bull and Boar Sperm Plasma Membranes. Cryobiology 1990, 27, 171-183. [CrossRef]

58. Holt, W.V.; North, R.D. Thermotropic Phase Transitions in the Plasma Membrane of Ram Spermatozoa. Reproduction 1986, 78, 447-457. [CrossRef]

59. Sanocka, D.; Kurpisz, M. Reactive Oxygen Species and Sperm Cells. Reprod. Biol. Endocrinol. RBE 2004, 2, 12. [CrossRef]

60. Nevo, A.C.; Rikmenspoel, R. Diffusion of ATP in Sperm Flagella. J. Theor. Biol. 1970, 26, 11-18. [CrossRef]

61. Plaza Davila, M.; Martín, P.; Tapia, J.; Ferrusola, O.; Balão da Silva, C.; Peña, F. Inhibition of Mitochondrial Complex I Leads to Decreased Motility and Membrane Integrity Related to Increased Hydrogen Peroxide and Reduced ATP Production, While the Inhibition of Glycolysis Has Less Impact on Sperm Motility. PLoS ONE 2015, 10, e0138777. [CrossRef]

62. Losano, J.; Angrimani, D.; Dalmazzo, A.; Rui, B.; Brito, M.; Mendes, C.; Kawai, G.; Vannucchi, C.; Assumpção, M.; Barnabe, V.; et al. Effect of Mitochondrial Uncoupling and Glycolysis Inhibition on Ram Sperm Functionality. Reprod. Domest. Anim. 2017, 52, 289-297. [CrossRef]

63. Bilodeau, J.-F.; Chatterjee, S.; Sirard, M.A.; Gagnon, C. Levels of Antioxidant Defenses Are Decreased in Bovine Spermatozoa After a Cycle of Freezing and Thawing. Mol. Reprod. Dev. 2000, 55, 282-288. [CrossRef]

64. Tourmente, M.; Villar-Moya, P.; Rial, E.; Roldan, E.R.S. Differences in ATP Generation Via Glycolysis and Oxidative Phosphorylation and Relationships with Sperm Motility in Mouse Species. J. Biol. Chem. 2015, 290, 20613-20626. [CrossRef]

65. Aitken, J.; Fisher, H. Reactive Oxygen Species Generation and Human Spermatozoa: The Balance of Benefit and Risk. BioEssays 1994, 16, 259-267. [CrossRef]

66. Srivastava, S.; Chandra, A.; Bhatnagar, A.; Srivastava, S.K.; Ansari, N.H. Lipid Peroxidation Product, 4-Hydroxynonenal and Its Conjugate with GSH Are Excellent Substrates of Bovine Lens Aldose Reductase. Biochem. Biophys. Res. Commun. 1995, 217, 741-746. [CrossRef]

67. Fritz, K.S.; Petersen, D.R. Exploring the Biology of Lipid Peroxidation-Derived Protein Carbonylation. Chem. Res. Toxicol. 2011, 24, 1411-1419. [CrossRef]

68. Dutta, S.; Majzoub, A.; Agarwal, A. Oxidative Stress and Sperm Function: A Systematic Review on Evaluation and Management. Arab J. Urol. 2019, 17, 87-97. [CrossRef]

69. Aitken, R.J.; Gibb, Z.; Mitchell, L.A.; Lambourne, S.R.; Connaughton, H.S.; De Iuliis, G.N. Sperm Motility Is Lost In Vitro as a Consequence of Mitochondrial Free Radical Production and the Generation of Electrophilic Aldehydes but Can Be Significantly Rescued by the Presence of Nucleophilic Thiols. Biol. Reprod. 2012, 87. [CrossRef]

70. Ayala, A.; Muñoz, M.F.; Argüelles, S. Lipid Peroxidation: Production, Metabolism, and Signaling Mechanisms of Malondialdehyde and 4-Hydroxy-2-Nonenal. Oxid. Med. Cell. Longev. 2014, 2014, 1-31. [CrossRef] [PubMed]

71. Agrawal, Y.P.; Vanha-Perttula, T. Glutathione, L-Glutamic Acid and $\gamma$-Glutamyl Transpeptidase in the Bull Reproductive Tissues. Int. J. Androl. 1988, 11, 123-131. [CrossRef] [PubMed]

72. Ntemka, A.; Tsakmakidis, I.A.; Kiossis, E.; Milovanović, A.; Boscos, C.M. Current Status and Advances in Ram Semen Cryopreservation. J. Hell. Vet. Med. Soc. 2018, 69, 911. [CrossRef]

73. Câmara, D.R.; Silva, S.V.; Almeida, F.C.; Nunes, J.F.; Guerra, M.M.P. Effects of Antioxidants and Duration of Pre-Freezing Equilibration on Frozen-Thawed Ram Semen. Theriogenology 2011, 76, 342-350. [CrossRef] [PubMed]

74. dos Santos Hamilton, T.R.; de Castro, L.S.; de Carvalho Delgado, J.; de Assis, P.M.; Siqueira, A.F.P.; Mendes, C.M.; Goissis, M.D.; Muiño-Blanco, T.; Cebrián-Pérez, J.Á.; Nichi, M.; et al. Induced Lipid Peroxidation in Ram Sperm: Semen Profile, DNA Fragmentation and Antioxidant Status. Reproduction 2016, 151, 379-390. [CrossRef]

75. Ashworth, P.J.; Harrison, R.A.; Miller, N.G.; Plummer, J.M.; Watson, P.F. Survival of Ram Spermatozoa at High Dilution: Protective Effect of Simple Constituents of Culture Media as Compared with Seminal Plasma. Reprod. Fertil. Dev. 1994, 6, 173-180. [CrossRef] 
76. Amidi, F.; Pazhohan, A.; Shabani Nashtaei, M.; Khodarahmian, M.; Nekoonam, S. The Role of Antioxidants in Sperm Freezing: A Review. Cell Tissue Bank. 2016, 17, 745-756. [CrossRef]

77. Gharagozloo, P.; Aitken, R.J. The Role of Sperm Oxidative Stress in Male Infertility and the Significance of Oral Antioxidant Therapy. Hum. Reprod. 2011, 26, 1628-1640. [CrossRef]

78. Allai, L.; Benmoula, A.; Marciane Da Silva, M.; Nasser, B.; El Amiri, B. Supplementation of Ram Semen Extender to Improve Seminal Quality and Fertility Rate. Anim. Reprod. Sci. 2018, 192, 6-17. [CrossRef] [PubMed]

79. Vernon, R.G.; Go, V.L.; Fritz, I.B. Studies on Spermatogenesis in Rats. II. Evidence That Carnitine Acetyltransferase Is a Marker Enzyme for the Investigation of Germ Cell Differentiation. Can. J. Biochem. 1971, 49, 761-767. [CrossRef] [PubMed]

80. Brooks, D.E. Carnitine, Acetylcarnitine and the Activity of Carnitine Acyltransferases in Seminal Plasma and Spermatozoa of Men, Rams and Rats. Reproduction 1979, 56, 667-673. [CrossRef]

81. Day-Francesconi, M.; Casillas, E.R. The Intracellular Localization and Properties of Carnitine Acetyltransferase from Ram Spermatozoa. Arch. Biochem. Biophys. 1982, 215, 206-214. [CrossRef]

82. Pruneda, A.; Yeung, C.-H.; Bonet, S.; Pinart, E.; Cooper, T.G. Concentrations of Carnitine, Glutamate and Myo-Inositol in Epididymal Fluid and Spermatozoa from Boars. Anim. Reprod. Sci. 2007, 97, 344-355. [CrossRef]

83. Solarska, K.; Lewińska, A.; Karowicz-Bilińska, A.; Bartosz, G. The Antioxidant Properties of Carnitine in Vitro. Cell. Mol. Biol. Lett. 2010, 15. [CrossRef]

84. Yang, K.; Wang, N.; Guo, H.-T.; Wang, J.-R.; Sun, H.-H.; Sun, L.-Z.; Yue, S.-L.; Zhou, J.-B. Effect of L-Carnitine on Sperm Quality during Liquid Storage of Boar Semen. Asian-Australas. J. Anim. Sci. 2019, 33, 1763. [CrossRef]

85. Aliabadi, E.; Soleimani Mehranjani, M.; Borzoei, Z.; Talaei-Khozani, T.; Mirkhani, H.; Tabesh, H. Effects of L-Carnitine and L-Acetyl-Carnitine on Testicular Sperm Motility and Chromatin Quality. Iran. J. Reprod. Med. 2012, 10, 77-82. [PubMed]

86. Deana, R.; Rigoni, F.; Francesconi, M.; Cavallini, L.; Arslan, P.; Siliprandi, N. Effect of L-Carnitlne and L-Aminocarnitine on Calcium Transport, Motility, and Enzyme Release from Ejaculated Bovine Spermatozoa. Biol. Reprod. 1989, 41, 949-955. [CrossRef]

87. Galarza, D.A.; Guevara, M.L.D.; Beltrán-Breña, P.; Sánchez-Calabuig, M.J.; Rizos, D.; López-Sebastián, A.; Santiago-Moreno, J. Influence of Sperm Filtration and the Addition of Glycerol to UHT Skimmed Milk- and TEST-Based Extenders on the Quality and Fertilizing Capacity of Chilled Ram Sperm. Theriogenology 2019, 133, 29-37. [CrossRef]

88. Galarza, D.A.; Santiago-Moreno, J.; Sebastian, L. Effect of L-Carnitine in a Skimmed Milk Based-Diluent on Membranes Preservation and Kinetic Activity of Ram Sperm under Chilled Conditions; Zaragoza. 2019. Available online: https://www. cabdirect.org/cabdirect/welcome/?target=\%2fcabdirect\%2fabstract\%2f20193404681 (accessed on 24 November 2021).

89. Souza, C.V.D.; Brandão, F.Z.; Santos, J.D.R.; Alfradique, V.A.P.; Santos, V.M.B.D.; Morais, M.C.D.C.; Rangel, P.S.C.; Silva, A.A.D.; Souza-Fabjan, J.M.G. Effect of Different Concentrations of L-Carnitine in Extender for Semen Cryopreservation in Sheep. Cryobiology 2019, 89, 104-108. [CrossRef] [PubMed]

90. Nascimento, J.M.; Shi, L.Z.; Tam, J.; Chandsawangbhuwana, C.; Durrant, B.; Botvinick, E.L.; Berns, M.W. Comparison of Glycolysis and Oxidative Phosphorylation as Energy Sources for Mammalian Sperm Motility, Using the Combination of Fluorescence Imaging, Laser Tweezers, and Real-Time Automated Tracking and Trapping. J. Cell. Physiol. 2008, 217, 745-751. [CrossRef]

91. Hereng, T.H.; Elgstøen, K.B.P.; Cederkvist, F.H.; Eide, L.; Jahnsen, T.; Skålhegg, B.S.; Rosendal, K.R. Exogenous Pyruvate Accelerates Glycolysis and Promotes Capacitation in Human Spermatozoa. Hum. Reprod. 2011, 26, 3249-3263. [CrossRef] [PubMed]

92. Ortiz-Rodríguez, J.M.; Martín-Cano, F.E.; Gaitskell-Phillips, G.L.; Silva, A.; Ortega-Ferrusola, C.; Gil, M.C.; Peña, F.J. Low Glucose and High Pyruvate Reduce the Production of 2-Oxoaldehydes, Improving Mitochondrial Efficiency, Redox Regulation, and Stallion Sperm Functiont. Biol. Reprod. 2021, 2021, ioab073. [CrossRef]

93. Giandomenico, A.R.; Cerniglia, G.E.; Biaglow, J.E.; Stevens, C.W.; Koch, C.J. The Importance of Sodium Pyruvate in Assessing Damage Produced by Hydrogen Peroxide. Free Radic. Biol. Med. 1997, 23, 426-434. [CrossRef]

94. Upreti, G.C.; Oliver, J.E.; Duganzich, D.M.; Munday, R.; Smith, J.F. Development of a Chemically Defined Ram Semen Diluent (RSD-1). Anim. Reprod. Sci. 1995, 37, 143-157. [CrossRef]

95. Wang, H.; Lu, J.; Kulkarni, S.; Zhang, W.; Gorka, J.E.; Mandel, J.A.; Goetzman, E.S.; Prochownik, E.V. Metabolic and Oncogenic Adaptations to Pyruvate Dehydrogenase Inactivation in Fibroblasts. J. Biol. Chem. 2019, 294, 5466-5486. [CrossRef] [PubMed]

96. Darr, C.R.; Varner, D.D.; Teague, S.; Cortopassi, G.A.; Datta, S.; Meyers, S.A. Lactate and Pyruvate Are Major Sources of Energy for Stallion Sperm with Dose Effects on Mitochondrial Function, Motility, and ROS Production. Biol. Reprod. 2016, 95, 34. [CrossRef]

97. Ashrafi, I.; Kohram, H.; Naijian, H.; Bahreini, M.; Poorhamdollah, M. Protective Effect of Melatonin on Sperm Motility Parameters on Liquid Storage of Ram Semen at $5{ }^{\circ} \mathrm{C}$. Afr. J. Biotechnol. 2011, 10, 6670-6674.

98. Jang, H.; Kim, Y.; Kim, B.; Park, I.; Cheong, H.; Kim, J.; Park, C.; Kong, H.; Lee, H.; Yang, B. Ameliorative Effects of Melatonin against Hydrogen Peroxide-Induced Oxidative Stress on Boar Sperm Characteristics and SubsequentIn VitroEmbryo Development. Reprod. Domest. Anim. 2010, 45, 943-950. [CrossRef]

99. Balao de Silva, C.M.; Macias-Garcia, B.; Miro-Moran, A.; Gonzalez-Fernandez, L.; Morillo-Rodriguez, A.; Ortega- Fervisola, C.; Gallardo- Balanos, J.M.; Stillwell, G.; Topea, J.A.; Pena, F.J. Melatonin Reduces Lipid Peroxidation and Apoptotic-like Changes in Stallion Spermatozoa. J. Pineal Res. 2011, 51, 172-179. [CrossRef] [PubMed]

100. Succu, S.; Berlinguer, F.; Pasciu, V.; Satta, V.; Leoni, G.G.; Naitana, S. Melatonin Protects Ram Spermatozoa from Cryopreservation Injuries in a Dose-Dependent Manner: Melatonin Mitigates Cryopreservation Injuries of Ram Spermatozoa. J. Pineal Res. 2011, 50, 310-318. [CrossRef] [PubMed] 
101. Reiter, R.J.; Tan, D.; Manchester, L.; Qi, W. Biochemical Reactvity of Melatonin with Oxygen and Nitrogen Species. Cell Biochem. Biophys. 2001, 34, 237-256.

102. Li, C.-Y.; Hao, H.-S.; Zhao, Y.-H.; Zhang, P.-P.; Wang, H.-Y.; Pang, Y.-W.; Du, W.-H.; Zhao, S.-J.; Liu, Y.; Huang, J.-M.; et al. Melatonin Improves the Fertilization Capacity of Sex-Sorted Bull Sperm by Inhibiting Apoptosis and Increasing Fertilization Capacitation via MT1. Int. J. Mol. Sci. 2019, 20, 3921. [CrossRef] [PubMed]

103. Du Plessis, S.S.; Hagenaar, K.; Lampiao, F. Thein Vitroeffects of Melatonin on Human Sperm Function and Its Scavenging Activities on NO and ROS. Andrologia 2010, 42, 112-116. [CrossRef] [PubMed]

104. Casao, A.; Mendoza, N.; Pérez-Pé, R.; Grasa, P.; Abecia, J.-A.; Forcada, F.; Cebrián-Pérez, J.A.; Muino-Blanco, T. Melatonin Prevents Capacitation and Apoptotic-like Changes of Ram Spermatozoa and Increases Fertility Rate. J. Pineal Res. 2010, 48, 39-46. [CrossRef]

105. Martin-Hildago, D.; Baron, F.J.; Bragado, M.J.; Carmona, P.; Robina, A.; Garcia- Marin, L.; Gil, M.C. The Effect of Melatonin on the Quality of Extended Boar Semen after Long-Term Storage at $17^{\circ} \mathrm{C}$. Theriogenology 2011, 75, 1550-1560. [CrossRef] [PubMed]

106. Fischer, T.W.; Kleszczyński, K.; Hardkop, L.H.; Kruse, N.; Zillikens, D. Melatonin Enhances Antioxidative Enzyme Gene Expression (CAT, GPx, SOD), Prevents Their UVR-Induced Depletion, and Protects against the Formation of DNA Damage (8-Hydroxy-2'-Deoxyguanosine) in Ex Vivo Human Skin. J. Pineal Res. 2013, 54, 303-312. [CrossRef] [PubMed]

107. Gibb, Z.; Aitken, R.J. Recent Developments in Stallion Semen Preservation. J. Equine Vet. Sci. 2016, 43, S29-S36. [CrossRef]

108. MaríN-Briggiler, C.I.; Tezón, J.G.; Miranda, P.V.; Vazquez-Levin, M.H. Effect of Incubating Human Sperm at Room Temperature on Capacitation-Related Events. Fertil. Steril. 2002, 77, 252-259. [CrossRef]

109. Kamada, Y.; Wakayama, S.; Shibasaki, I.; Ito, D.; Kamimura, S.; Ooga, M.; Wakayama, T. Assessing the Tolerance to Room Temperature and Viability of Freeze-Dried Mice Spermatozoa over Long-Term Storage at Room Temperature under Vacuum. Sci. Rep. 2018, 8. [CrossRef] [PubMed]

110. Pauw, I.M.C.D.; Soom, A.V.; Mintiens, K.; Verberckmoes, S.; Kruif, A.D. In Vitro Survival of Bovine Spermatozoa Stored at Room Temperature under Epididymal Conditions. Theriogenology 2003, 59, 1093-1107. [CrossRef] 